have books out for such a long time (fifteen years at one college library) that they have frequently forgotten about them, or the books have become part of their office fixtures. Often the books have been loaned to colleagues or even to students that have departed from the campus. Nothing much is done except to continue sending routine notices which often are not well received or are just plainly ignored unless someone else wants the book or unless the borrower is leaving for another position. Other libraries do not give up the fight, but persist in "requests, tears, threats and even prayers." Constant "nagging" and "personal harassment" are two other techniques that seem to work for some college librarians.

Among the research libraries, where more efficient machinery and formalized rules are in operation to enforce loan time limitation, the problem arises of the great amount of staff time needed for the mechanics of recall, renewal, and overdue notices. As an example, one southern university is forced to use one staff member full time for two or three months each year to take an inventory of books loaned to faculty members.
There is general agreement that faculty members should have extended privileges on library materials. This is necessary in order that they may keep up with publications in their field, and for teaching and research purposes. But it is no excuse for keeping a book for more than one year-at this point, it appears, they should purchase it themselves. The retort that a needed book can be recalled is not always valid. Many library users in an open shelf building, it is pointed out, browse through sections pertinent to their interest and are not looking for specific titles. Even when a specific title is sought, it is perhaps needed immediately and not next week or even tomorrow. Borrowers frequently hesitate to request a recall but rather see what else, if anything, they can find on the subject.

The growing masses of students besieging academic institutions, the current trend toward greater library use by students and the concomitant inability of libraries to keep up with these demands because of budget and staff limitations, are other factors cited which should deter libraries from allowing their books to lie unused and forgotten in faculty members' bookcases.

\title{
Attention: Junior College Librarians
}

This yeAR the Committee on Instruction and Use of the Junior College Libraries Section of ACRL is making a collection of junior college faculty library handbooks. Please send a copy of your library's faculty handbook to Mrs. Alice B. Griffith, Librarian, Mohawk Valley Community College, 1101 Sherman Drive, Utica 3, New York for inclusion in this collection. Since the committee plans to organize and study the collection, handbooks should be mailed by January 1, 1964. Your cooperation with the committee in this project will be appreciated.-Mrs. Alice B. Griffith, Chairman, Committee on Instruction and Use. 